\title{
DIFFERENCE AND THE ESTABLISHMENT: AN ASIAN CANADIAN SENIOR PASTOR'S EVANGELICAL SPATIALITY AT TENTH AVENUE ALLIANCE CHURCH IN VANCOUVER, BC
}

\author{
Diferença e Estabelecimento: A Espacialidade Evangelical de um Pastor Sênior Asiático \\ Canadense na Tenth Avenue Alliance Church em Vancouver
}

\author{
Justin K. H. Tse \\ University of Washington \\ Jackson School of International Studies, \\ Comparative Religion Unit \\ jkhtse@uw.edu
}

\begin{abstract}
This paper explores how the evangelical spatiality of an Asian Canadian senior pastor at a historically Anglo-Saxon congregation has transformed it from an ethnically homogeneous, aging church to a heterogeneously-constituted gathering in an evangelical Protestant tradition. This piece challenges the conventional wisdom of the church growth movement and the new religious economics in the sociology of religion, both of which advise religious groups to construct homogeneity and consensus in efforts for numerical growth over against secularizing forces. The paper argues instead that Pastor Ken Shigematsu's evangelical spatiality from the mid-1990s to the present must be understood as a theological embrace of difference in a church gifted to him by God over which he prayerfully pastors along with his staff. This paper understands Shigematsu's evangelical spatiality through his own New Testament exegesis, his denominational affiliation with the Christian and Missionary Alliance, his ancient spiritual practices of indiscriminate hospitality, and his mystical reception of Tenth as a welcoming space toward a multiplicity of ethnic, class, and religious backgrounds. This article contributes to Asian Canadian Christian studies by discouraging a future where panAsian churches in Canada are homogeneously constructed and by exploring the concrete possibility of non-strategies in which heterogeneous, complex spaces that include Asian Canadians are received by pastors and studied by academics as a divine gift.
\end{abstract}

Keywords: Asian Canadian, Evangelical, Difference, Space, Place, Geographies of Religion.

RESUMO: Este artigo explora como a espacialidade evangelical de um pastor sênior asiático canadense, em uma congregação anglo-saxônica histórica, tem se transformado de uma igreja etnicamente homogênea e envelhecida para uma mais heterogênea em uma tradição protestante evangelical. Este trabalho desafia o saber tradicional do movimento de crescimento de igrejas e da nova economia religiosa na sociologia da religião; em que ambos aconselham grupos religiosos a se constituírem de forma homogênea e consensual, com o fim de atingirem crescimento numérico em face das forças secularizantes. $O$ presente artigo defende, ao contrário, que a espacialidade evangelical do pastor Ken Shigematsu, de meados de 1990 até o presente, deve ser entendida como uma conjunção teológica da diferença em uma igreja dada a ele por Deus; e sobre qual o mesmo devotamente pastoreia juntamente com sua equipe. Este trabalho entende a espacialidade evangelical de Shigematsu através da sua própria exegese do Novo Testamento, da sua filiação a Aliança Missionária Cristã, das suas antigas práticas 
espirituais de hospitalidade indiscriminada, e da sua recepção mística na Tenth como um espaço de acolhimento para a multiplicidade étnica, de classe e de backgrounds religiosos. Este artigo contribui para os estudos sobre Cristianismo Asiático Canadense desencorajando um futuro em que igrejas pan-asiáticas no Canadá são homogeneamente construídas e explorando uma possibilidade concreta de não-estratégias em que espaços heterogêneos e complexos, que incluem asiáticos canadenses, são recebidos por pastores e estudados por acadêmicos como uma dádiva divina.

Palavras chave: Cristianismo Asiático Canadense, Evangelical, Diferença, Espaço, Lugar, Geografias da Religião.

\section{Introduction: Establishing Tenth}

Tenth Avenue Alliance Church in Vancouver, British Columbia seems to be an ideal site for an Asian Canadian congregational study. Averaging 1600 attendees per Sunday and 3000-4000 during Christmas, it is one of the largest churches in Metro Vancouver. Its senior pastor is Asian, a Japanese Canadian who has lived in Asia, England, and various parts of North America, who once worked for SONY in Tokyo, and who has pastored at Tenth since the mid-1990s. Its congregational demographic reflects a sea of diversity, a multicultural mosaic that seems to reflect Canadian values. Indeed, its size seems to make it ideal for an article on church growth, its demographic makeup for a sociological congregational study, the presence of Asians up to its senior leadership for a simple Asian Canadian Christian exposition.

This paper resists such conventional interpretations. It seeks to understand Tenth as a space where a particular strand of evangelical Christian theology that embraces difference is worked out. It engages both the church growth movement and the "new religious economics" in recent sociologies of religion with an alternative reading of Tenth that emphasizes the congregation as a heterogeneous religious space. Indeed, it holds that conventional sociological congregational studies (including the church growth movement) lend themselves to epistemic violence by imposing secular categories on the theological practices of Christian congregations (VOLF, 1996; MILBANK, 2006; LEY; TSE, 2011). Instead, Tenth is better interpreted through the "socio-theological paradigms" operating within the congregation, an approach that examines the traditions that inform lived religion in specific historical and geographical contexts (JUERGENSMEYER, 2010, p.10-11; see also ASAD, 1993; 2003; PRIMIANO, 1993; ORSI, 1999; 2001; DWYER 1999a; 1999b; KONG, 2001; 2010; 
FALAH; NAGEL, 2005; STUMP, 2008; GOKARIKSEL, 2009; MACDONALD, 2010; DAGGERS, 2010).

I argue that Tenth challenges the conventional wisdom of religious establishments where it is assumed that religious congregational homogeneity needs to be constantly constructed (see TSE, 2010). I do so by elaborating evangelical spatial practices at Tenth that are faithful to the Gospel of Jesus Christ by emphasizing radical hospitality. Such an approach results in an embrace of difference within a congregation, not the manufacturing of a pragmatic marketability that seeks to construct ethnic and class homogeneity for mass palatability. In so doing, I suggest that the Asian Canadian elements of Tenth during Ken Shigematsu's senior pastoral tenure from the 1990s to the present are better interpreted as a challenge to mono-ethnic religious establishments, interrupting the conventional notion that Christians in North America must voluntarily congregate by sociological similarities (see WARNER, 2005). Indeed, this paper voices the concern that assumptions about congregational homogeneity as a normative "social fact" will lead religious congregations to read such studies as prescriptive (see MILBANK, 2006). In so doing, it resists what Miroslav Volf (1996, p.74) has termed "false purity" by demonstrating through Ken Shigematsu's evangelical spatiality at Tenth Avenue Alliance Church that Christian congregations can exist as complex heterogeneously-constituted spaces, serving as viable alternatives to predominantly homogeneously-constructed models.

This paper is based on an interview conducted by Ken Shigematsu in 2011 that has been put in conversation with his other public writings. It moves in three parts. First, I examine an evangelical theology of difference as a key socio-theological paradigm operating at Tenth through Pastor Ken Shigematsu's exegesis of Galatians 2:11-21 as central to his understanding of the Christian Gospel. Second, I demonstrate that Tenth's embrace of difference can be read through Shigematsu's modern denominational affiliation and ancient spiritual practices so as to confound the (albeit well-intentioned) economistic constructivism of the church growth movement and the new religious economics. Third, I trace the theological practice of evangelical difference as a divine gift mystically received through Shigematsu's prayer life and pastoral work at Tenth. I conclude that Tenth's Asian Canadian elements converge with Jonathan Tran's (2010b) call for Asian American Christianity to de-whiten perceptions 
of North American Christianity so that Christianity can be seen as a "complex space" where sociological differences thrive (MILBANK, 1997, p.268-292).

\section{An Evangelical Theology of Difference: Ken Shigematsu and Galatians 2:11-21}

We begin with biblical hermeneutics because the Christian Scriptures are key to Ken Shigematsu's theological methodology and pastoral philosophy as an evangelical pastor. Shigematsu's evangelical theology as read through Galatians 2:1121 is a key passage through which he interprets his own congregation at Tenth. This exposition is necessary because it allows Shigematsu to define for himself what he means when he describes himself as an evangelical Christian pastor without the contemporary political baggage associated with American evangelical eschatological pronouncements and neo-conservative geopolitics (see DITTMER; STURM, 2010). Just as Tim Tseng (2002) explored the connection between second-generation Chinese American Christians and the way they defined their roles in Chinese churches, this examination of Shigematsu's reading of the New Testament helps us to better understand his ministry philosophy. Such an approach opens a window into a particular understanding of Asian Canadian ministry at Tenth that emphasizes the theological formation of a heterogeneous community, not a homogeneous institution (see LEY; TSE, 2011).

Ken Shigematsu's understanding of the Gospel places an embrace of difference at the centre of the evangelical message (see VOLF, 1996). He bases this conviction on an exegetical study of Galatians 2:11-21 that he performed in 1992 for a New Testament exegesis course at Gordon-Conwell Theological Seminary. ${ }^{1}$ In his paper, Shigematsu argued in line with the "New Perspective" on Pauline studies that Paul's main concern was the relationship between Jew and Gentile, not a Luther-like agonizing over personal

\footnotetext{
${ }^{1}$ As our article draws on Shigematsu's seminary exegesis paper from 1992, the literature provided in this section understandably dates back to the 1980s and 1990s. Our goal is not to produce a current, comprehensive review of New Testament studies on a theology of difference but to examine how Ken Shigematsu understands difference through his reading of the New Testament and how this theology was developed during his studies at Gordon-Conwell Theological Seminary in the early 1990s.
} 
assurance of salvation. ${ }^{2}$ As J. D. G. Dunn (1990) and N. T. Wright (1992) have argued, Paul insisted that the Gentiles were included as full and genuine heirs to the promises of God to Israel, relativizing the Torah as a boundary marker of Jewish distinctiveness as God's chosen people.

Shigematsu also falls in line with contemporary New Testament studies that understand early Christianity before $\mathrm{AD} 70$ as a sect within Judaism. In this understanding, God-fearing Gentiles were embraced by a Jewish church whose geographical centre of authority was the Jerusalem ekklesia. During Paul's time, the Jews believed that their distinctive religious and national prerogatives were being increasingly threatened by the deteriorating political climate in Palestine (DUNN, 1990, p.132-33; see also WRIGHT, 1992). Jewish authorities responded to this threat by pressuring Jewish Christians (of whom God-fearing Gentiles were seen as a part) to show themselves as faithful and loyal Jews. As Dunn (1990, p.134) further explains, Jewish believers took it for granted that Gentiles would be circumcised if they were to share in the Jewish heritage. Wright (1992) also elaborates that other Second Temple Jewish cultural boundary markers also included certain eating practices and observing special days on the festival calendar. Moreover, Jewett (1984) notes that Jews who fraternized with Gentiles in table fellowship were often vulnerable to Zealot reprisals. If Gentile Christians were persuaded to accept circumcision, such Jews might be protected from Zealot vengeance stemming from a politicized Palestinian space (JEREMIAS, 1971).

Table fellowship with Gentiles at Antioch was thus seen as a threat to Second Temple Judaic political unity, an offence that Peter sought to avoid by separating himself from Gentile Christians at table when a conservative Jewish Christian contingent arrived in Antioch from Jerusalem. Peter's tactical move may have been motivated by his fear of Zealot Jews and the political consequences of being reported to Jerusalem, which could have caused a rift between the Jerusalem and Antioch churches (JEWETT, 1984). Paul calls Peter's pragmatic decision sunupekrithesan-“play-acting"

\footnotetext{
${ }^{2}$ We understand the "New Perspective on Paul" to refer to studies pioneered by E.P. Sanders (1977. 1983), James Dunn (1990), and N.T. Wright (1992) that argue against a Reformed interpretation of Paul as emphasizing justification by faith alone over against works. Instead, their approach underscores the context of Second Temple Judaism in first-century Palestine and contends that Paul was setting himself against the need for Gentile Christians to submit to the cultural Jewish boundary markers of circumcision, dietary laws, and Sabbath-keeping in order to be counted as part of the people of God.
} 
to conceal one's true character, thoughts, and feelings under a guise-because Peter's previous theological practice had already led him to relativize the Jewish boundary markers and have table fellowship with Gentiles, even though he was a person of Jewish ancestry. Compelling Gentiles to Judaize out of political expediency was a theological undermining of the Gospel of Jesus Christ, especially because Peter had already lived like a Gentile. As Betz (1979, p.112) points out, by going back to the Torah, Peter betrayed a core Christian theological conviction that no one could be saved by the Torah. He was implicitly demanding that the Gentiles fall under the cultural boundary markers of Second Temple Judaism to be accepted by God.

As Shigematsu reads it, Peter's tactical withdrawal had ramifications for the equal footing of Jews and Gentiles in the redemptive history eschatologically fulfilled by Christ. A Pauline theology holds that Christ already fulfilled his promises made to Abraham to bless the nations (Gen. 17:7) when God poured out the Holy Spirit on the Gentiles without their adherence to the Torah (Acts 2:1-12, 33-38; 10-45-47; 11:17-18; 15:8). Peter's separation from the Gentiles would have implied that the Gentiles were deficient second-class citizens in the kingdom unless they became culturally Jewish. The Torah, not the Gospel of Jesus Christ, would have become the basis of Christian unity, a disaster for a church that had based itself on the relativization of cultic separation for the inclusion of all humanity. It would also have subjected non-Jewish Christians to keep the whole Torah, an impossibility for Paul because the law condemns its adherents as lawbreakers (Gal. 3:1-4). As Dunn (1990; see SANDERS, 1983, p.75) points out, justification by faith and covenantal nomism are not complementary but are in contradiction to each other.

Based on this exegesis that takes seriously the context of Second Temple Judaism, Shigematsu argues that Paul used the incident at Antioch to demonstrate that Peter was in the wrong because his pragmatic compromise with a conservative Jewish establishment demonstrated that the Gentiles had not been fully received into the new covenant of Jesus and that the doctrine of justification through Christ was nullified (Gal. 2:15-16). While Peter had not consciously wanted to move the basis of Christian unity to the Torah, his adoption of a culturally Jewish boundary marker denied the revelation of God in Jesus Christ. Such a tactic is a theological compromise resulting in further ecclesial divisiveness, for it denies the basis of the liberating message of unity in 
Galatians 3:28 that "there is neither Jew nor Greek, neither slave nor free, neither male nor female" because all are one in Jesus Christ. As Shigematsu reads Paul, theological compromise that shifts the basis of unity from Jesus Christ leads to church splits.

For Shigematsu, this "New Perspective" reading of Galatians 2:11-21 is the source for an evangelical ecclesiology that emphasizes difference in the space of a Christian ecclesial congregation, whether the context was Antioch or is Vancouver. Such an emphasis on the exegesis of a biblical text in Ken Shigematsu's theological practice locates Shigematsu as an evangelical pastor-theologian with a particular understanding of the Gospel. This evangelical theology is not simply a conversionary soul-searching for assurance of faith (see BEBBINGTON, 1989); rather, it is evangelical in the sense that the evangel of Jesus revealed in the Scriptural text has implications for how to govern a Christian congregation. Shigematsu's evangelicalism takes after Miroslav Volf's (1996, p.51-53) biblical theology of embrace that acknowledges the need for Christians to develop a "catholic personality" that makes space for the other as well as a prophetic "evangelical personality" to bear witness against the "false purities" that breed exclusionary practices. John Milbank (2006, p.56) has also called Christians to revisit a theology where difference is not assumed to lead to violence; instead, heterogeneity in the city of God should be thought of in terms of "harmonic peace," forming a "complex space" where sins are forgiven and differences are reconciled (see MILBANK, 1997). Emphasizing such an evangelical ecclesiology, Shigematsu decouples the all-too-often necessary pairing of "conservative" and "evangelical" by showing that conservative approaches to community that emphasize homogeneity for marketability are at odds with the Gospel as articulated by Paul in his letter to the Galatians. Indeed, Shigematsu's reading of Galatians 2 frames such politically correct strategies as heterodox compromises of the Gospel for which Paul rebuked Peter. Difference, not homogeneity, is normative in Christian space according to Shigematsu's reading of Paul.

Confounding Church Economism: Shigematsu's Alliance Tradition and Ancient Spiritual Practices as Challenges to the Church Growth Movement and the New Religious Economics 
Shigematsu's Christian hermeneutic makes us ambivalent about interpreting the church he pastors through conventional paradigms both within the theological academy in the church growth movement and without seminaries in social scientific studies of religion that fall under the rubric of the new religious economics. In this section, I critique the positivistic assumptions behind the economism of such congregational studies and provide an alternative reading of Tenth as a unique spatial expression of the theology of the Christian and Missionary Alliance denomination. This theology can be succinctly articulated as an ancient cruciform practice that confounds conservative establishmentarianism with its indiscriminate hospitality.

\section{Strategic economism: constructing and contesting congregational homogeneity}

The church growth movement and the new religious economics are surprisingly similar in their economistic approaches that emphasize the homogeneity of religious congregations. Granted, both literatures are well-intentioned in their resistance to secularizing processes. The church growth movement grows out of a Christian missiology that takes its cue from the Great Commission in Matthew 28. Growing out of missionary work in India, Donald McGavran ([1954]2005) demonstrated that homogeneous ethnic groups were more effective in their growth and social impact. Leaders in the church growth movement adapted such an approach to grow their own churches by attracting a homogeneous suburban "seeker" ideal type and training them in small groups (see GEORGE, 1991; GEORGE; BIRD, 1993; WARREN, 1995; LOGAN; GEORGE, 1996). In these church models, homogeneity in the church was a method of resisting secularization in the mission field and growing the Christian church. Such approaches were often economistic: to strategically oppose secularity, pastors were told to market their churches to maximize their fulfillment of the Great Commission. Christian congregations were informed that they had to be relevant to seekers by selling the Gospel in sociologically relevant ways so as to expand the realm of God over against the spatial control of a godless, technocratic world. Often, this meant that congregations were assumed to be more effective if there were fewer differences in their demographic makeup, epitomized in "seeker services" where a palatable message would be preached to a homogeneous gathering of non-religious 
seekers separate from a main service where already-converted Christians could delve deeper into systematic doctrine. As Justin Wilford (2010) notes, these large churches have had the effect of creating "sacred archipelagos" in a sea of secularizing social conditions. ${ }^{3}$

Likewise, the new religious economics resists simple secularization theses in North America that hold that religion is irrational; over against irrationality, sociologists of religion emphasize that religious practitioners make market-driven, rational choices as to where they worship. For Stark and Finke (2000), religions exist in a religious economy in which religious groups operate at different intensities. As they see it, the stricter the intensity of a religious sect, the more distinctiveness it can muster to market to potential practitioners. This new religious economics falls under the larger rubric of the "new paradigm" in the sociology of religion that emphasizes a voluntarism and congregationalism in North America that developed in the revivals of the Second Great Awakening (WARNER, 2005). Such sociologies of religion, like the church growth literature, attempt to demonstrate that religion is far from a dying, irrational force. They argue instead that the majority of religious adherents practice their religion in rational, economic ways that emphasize their own voluntary agency. Given voluntary choice, these practitioners will naturally congregate with persons who are similarly motivated to join sects that have done well in the religious marketplace. These choices tend to form various types of homogeneous religious congregations, including liberal churches, conservative churches, Asian churches, African churches, gay churches, and so on (see WARNER, 2005).

What is often left tacit in sociological congregational studies is that such strategic homogeneity in an effort to resist secularization processes must be constructed. Indeed, the church growth movement has emphasized the so-called necessity of targeting homogeneous groups of people because they argue that there will be more receptivity to the Gospel if people do not need to cross cultural, economic, or racial lines. While well-intentioned, this approach assumes that homogeneity is a social fact, eliding the reality that it is a contested and constructed strategy to numerically expand a religious space. As Milbank (2006, p.73-74) reminds us, the Durkheimian positivist

\footnotetext{
${ }^{3}$ Granted, as Wilford (2010) also notes, the "sacred" in these "sacred archipelagos" has itself been affected by secularization, for secularization produces new religious forms. This is also a point made strongly by Charles Taylor (2007).
} 
sociology that undergirds such assumptions tacitly holds that the world is arbitrarily ordered by "the necessary violence of sacrifice" so that a homogeneous society, whether the post-revolutionary nation-state of France or a Christian congregation in North America, must be continually purged for social purity. Therefore, while R. Stephen Warner (1998) is right to notice that voluntary congregations often attract sociologically similar persons, his congregational ethnographies tend to overlook the reality that consensus in such congregations has to be continually constructed and is often tenuous at best. Indeed, within Warner and Wittner's (1998) classic volume on congregations, the studies that focus on how ethnic congregations are constructed are laden with stories of contestation. For example, Karen Chai (1998) describes the exhausting competition in a Korean American church in Boston for the attention of its second generation over against on-campus groups. Likewise, Fenggang Yang (1998) explores the "tenuous unity" that always seems to have explosively divisive potential between Chinese subethnic groups at a mostly Mainland Chinese church in Washington DC. In both cases, homogeneity in religious congregations is certainly not a given social fact; it is better described as a struggle to maintain consensus. Similarly, Tse (2010) demonstrates that a Hongkonger congregation in a Vancouver suburb has unwittingly retained its subethnic, transnational identity through everyday habits of maintaining Cantonese as a normative Chinese language and invoking common religious educational backgrounds received in Hong Kong. These practices have the unintended effect of excluding mainland Chinese migrants who speak Mandarin and who do not share the pedigree of a Hong Kong religious education (see also LEY; TSE, 2011). Again, homogeneity in churches tends to be constructed through self-defining tactics that may not be intended to draw boundaries between populations but end up necessarily excluding sociological misfits from ethnic- and class-specific congregational spaces.

Moreover, the contestations that go into forming social capital in religious congregations often only last over the short term because they tend to be generationally contingent. Indeed, churches that began by catering to certain migrants run the risk of becoming increasingly exclusive because they construct their social capital along ethnic lines (BEATTIE; LEY, 2003; LEY, 2008; LEY; TSE, 2011). As Ley (2008) argues, bonding social capital in congregations through ethnicity usually gives way after one generation to bridging social capital between generations and ethnicities. One German 
pastor in Ley's sample spoke of a "cultural funeral" in which the shrinking of the congregation due to the departure of the second generation precipitated a "full transition from an ethnic to a Canadian congregational identity, rupturing the tight bonds between faith, language, and identity" (LEY, 2008, p.2068). As Ley and Beattie (2003) have shown, some German churches in Vancouver became heterogeneous spaces where the German heritage was largely invisible behind the contemporary ethnic diversity. Indeed, the irony is that pragmatic homogeneity in one generation must give way to heterogeneity for practical reasons if a congregation is to survive over time. Social capital is not static; it is dynamically forged through relationships within congregations, and when new generations and ethnicities challenge those relational constructions, the congregation is forced to face the prospects of change. As Shigematsu (1996) once put it, the "ethnic" church in Canada must inevitably cross the threshold into becoming "multi-ethnic," a multicultural Canadian perspective that converges with Asian American theologian Jonathan Tran's (2010a) assertion that there is no future for Asian American churches if they insist on creating exclusively pan-Asian spaces. In short, there is nothing natural, permanent, or peaceable about the construction of homogeneous religious congregations. While such social formations are all too wellintentioned, the processes of constantly constructing such spaces are often fraught with congregational divisiveness, unintentional exclusivity, and generational exodus.

\section{Shigematsu's theological traditions as non-strategic pastoring: the Christian and Missionary Alliance and early Christian practices of indiscriminate service}

While the literature we have reviewed has identified congregational homogeneity as a contested strategy for church growth and survival, we ask: are these terms of construction, contestation, and survival sufficient paradigms through which to read Tenth? As Milbank (2006, p.5) has argued, such an approach imposes the assumption that churches operate with an "ontology of violence" while orthodox Christian theology focuses on an alternative existence based on peaceable communion. Instead of merely asking these empirical questions about Tenth, we must also ask: what are the sociotheological paradigms and traditions at work at Tenth through its senior pastor, Ken Shigematsu? This question about theological complexity is our resistance to the sociological conservatism that seems to not only describe but to univocally 
prescribe congregational contestation and economistic homogeneity as the only way to resist secular encroachment. Such a prescription is heterodox to a Christian theology based on love and peaceable communion, and while the studies outlined above have described the commonness of congregational disunity, an empirical norm should not be prescribed as a course of action. Instead, Ken Shigematsu's evangelical spatiality of difference demonstrates that while demographic homogeneity in religious establishments is arguably the goal and reality of many contemporary churches, it is not necessarily a given social fact. Rather, Shigematsu's theological practice reveals that Christian congregations often must break with such normative, strategic conventionalism in order to pursue a mission of serving the city in which a congregation finds itself. This is because, like Peter in Galatians, well-intentioned strategies of homogeneity to avoid political offence and to maximize evangelistic fruit are in fact heterodox theological compromises that substitute sociology for Jesus Christ as the basis of Christian unity. Over against this, Shigematsu sees himself not as a leader who constructs congregational consensus at Tenth but as a pastor who is connected to two theological traditions that emphasize difference: a modern denominational affiliation with the Christian and Missionary Alliance as well as a personal affinity with early Christian practices of indiscriminately serving the needy.

If one must categorize Ken Shigematsu and his church, it is better to see them first within their own denominational network, the Christian and Missionary Alliance, for (in Shigematsu's reading) this particular evangelical tradition was born out of a theological embrace of difference. A seminal moment in Alliance founder A.B. Simpson's story for Shigematsu is when Simpson decided to depart from his Presbyterian church in New York because his elders rejected his desire to work with the poor (see THOMPSON, [1920]2008; TOZER, 1943; REYNOLDS, 1982; 1992; HARTZFELD; NIENKIRCHEN, 1986; REITZ, 1991; NIENKIRCHEN, 1992; REID, 1997). As the pastor of the wealthy Thirteenth Street Presbyterian Church in New York City in the late 1800s, Simpson notably made four times the salary of a typical nineteenth-century Manhattan attorney. Undeterred by his financial success, he began an outreach ministry to Italian and Greek migrants, attempting to integrate them into his church. When the conservative elders of the established church opposed him on the grounds that Simpson's actions would disturb the socioeconomic and ethnic 
homogeneity of the church, Simpson resigned his pastorate, leaving the security of his salary and reached out to more marginzalized groups among migrants to New York, including single mothers, the socio-economically deprived, and sex-trade workers. For Shigematsu, the Christian and Missionary Alliance began with an embrace of difference based on an evangelical theology of reaching the least of these, a Christian spatiality that provoked opposition from and rupture with the conservatism of a homogeneous establishment. In this sense, Simpson's option for the poor was economically irrational in its sacrifice of wealth and prestige to be among people who could not pay him back.

At Tenth, Shigematsu sees himself as the inheritor of this Simpsonian tradition. $\mathrm{He}$ is a person of Japanese ancestry pastoring in a historic Anglo-Saxon church in Vancouver. When he was hired, some established members left in protest, believing that it was a mistake to hire someone so different from themselves. ${ }^{4}$ A telling moment for Shigematsu was when he introduced himself to an elderly Anglo-Saxon woman at the end of one of his first Sundays. She replied: "Why did we have to hire someone who was our enemy during the war?" referencing his Japanese ancestry as putting them at historical odds because of the events of World War II. Indeed, Shigematsu's very presence as he inhabited a different ethnic body precipitated a split in a historically homogeneous establishment during his early years in ministry at Tenth.

However, the elders at Tenth had hired Shigematsu because they themselves wanted to break with the prevailing culture of their racially homogeneous congregation. As such, they hired an ethnic minority senior pastor who reflected the new Asian Canadian demographic of Vancouver in the 1990s (see SKELDON, 1994; LEY, 1995; 2003; 2010; OLDS, 1996; MITCHELL; OLDS, 2000; WATERS, 2002; 2003; 2006; MITCHELL, 2004; LI, 2005; LEY; KOBAYASHI, 2005; YU, 2008). They soon discovered that changes to the senior pastor's ethnicity also meant changes to the homogeneous aging culture of the church because that pastor was thirty years old and single. A concrete example of this Simpsonian shift was in Tenth's sudden change in musical style. The worship director asked Shigematsu early on what he thought about

\footnotetext{
${ }^{4}$ It is not true, however, that Tenth Avenue Alliance Church has been historically uninterested in mission work to Asians in Vancouver, for they housed the non-Chinatown portions of the work of Vancouver Chinese Alliance Church before they moved to Knight Street with 200 congregants in 1970 (CHAO; YU, 2002, p.79-81). They also supported missionary work in China. But as Jiwu Wang (2006) notes, such missionary efforts were often historically accompanied by unexamined orientalist beliefs that sometimes undermined Christian evangelism.
} 
the music, and he replied honestly: "I feel like it appeals more to white, older people. It reminds me of the Lawrence Welk show." His response implied that though he was senior pastor, he felt excluded from the church as a non-white, young person. When the worship leader followed Shigematsu's suggestions to buy drums, her actions created a conflict within the church. Epitomizing the clash, someone exclaimed a few weeks later: "If Jesus saw those drums on the platform, he would roll over in his grave right now!" But the music director stood firm with her break with the prevailing homogeneous culture in terms of musical style because she had to establish that Tenth was not built on a homogeneous age group with certain stylistic preferences. Indeed, while such decisions initially resulted in conflict, the opposition could be interpreted as the resistance of a historically homogeneous congregation to changes that better reflected an evangelical theology of difference by making space for sociological others. For Shigematsu, such backlash is woven into the Alliance tradition, as Simpson forsook the wealthy establishment to practice difference among the poor. The musical changes were not a strategy to create a new homogeneity as a missional strategy; if anything, they followed in the footsteps of Simpson's strategic economic blunders characterized by their threat to congregational homogeneity and their driving away of the rich, powerful, and established, if only to follow a more faithful evangelical Christian practice. Constructing homogeneity was a practice that had to be forsaken at Tenth even if it meant offending the establishment in the early years of Shigematsu's pastorate.

As Shigematsu sees it, such a heterogeneous approach that makes little economic sense follows a Christian and Missionary Alliance ecclesiology that is faithful to the orthodox Christian practice of indiscriminate service in the early church. Shigematsu is often reminded of a fourth-century letter written by the pagan emperor Julian the Apostate to plead for pagans to emulate the charity of Christians by establishing hostels for weary travelers throughout the empire just as Christian bishops exhorted all Christians to care for all persons, both Christian and pagan. As the emperor put it bluntly, “...it is disgraceful when no Jew is a beggar and the impious Galileans support our poor in addition to their own; everyone is able to see that our coreligionists are in want of aid from us" (KOELLER, 2005). This reading references Shigematsu's New Testament convictions about difference in the Antiochene clash between Peter and Paul, but it also demonstrates that Shigematsu's reading of difference as a key practice 
in Christian origins extends into the late patristic period. Indeed, for Shigematsu, the modern Alliance way is in direct consonance with the practice of the early church with its breaks with the wealthy homogeneous establishment for the sake of reaching out to the poor, the marginalized, and the migrants. To construct homogeneity to please the establishment, to manage consensus, or to pursue strategic evangelism is a betrayal of the practice of non-discriminating hospitality in early Christianity, of which Shigematsu as an Alliance pastor sees himself a part.

We have argued in this section that Tenth's practice of A.B. Simpson's Alliance spatiality confounds the conventional congregational hermeneutics of church growth and the new religious economics. For Shigematsu, practices that favour difference and poverty are ultimately derived from an understanding of Christian discipleship as a cruciform act. As Shigematsu (2011a) recently preached from Luke 9, he quoted Bonhoeffer (2001, p.44) while picking up a life-sized cross: "When Christ calls a man he bids him to come and die...Following Jesus is costly because it will cost your life, but it is grace because it gives you your only true life." When some people walked out, Shigematsu felt confirmed that this message of the cross continued to offend the conservative establishment interested in constructing a homogeneous status quo. As well-intentioned as the conservatism of new sociologies of religion and missiologies are, their emphasis on the rationality of religion overlooks the reality that Christians walk in a tradition like those to whom the Emperor Julian referred, A.B. Simpson, and Ken Shigematsu. The practice of indiscriminate service and hospitality defies economic rationality as such Christians follow in the footsteps of a crucified Lord instead of self-describing as rational consumers of a generic deity and sect. The issue for Christian congregations, particularly those that identify as Asian Canadian, may not be strategies to create consensus among a conventional congregation. Instead, a new question for Asian Canadian Christians is how Christian communities can be forged in spite of a cruciform Christian Gospel that continues to offend proponents of homogeneity who persist in an unspoken ontology of constructivist contestation. 
This section examines four episodes during Ken Shigematsu's pastorate at Tenth that were concrete spatial expressions of his evangelical theology of difference. Shigematsu's mystical spirituality is highlighted here as part of Robert Orsi's (2001) call to understand religion in irreducible spiritual paradigms in which scholars must be immersed..$^{5}$ As such, this paper does not ask what Shigematsu's church management strategy "really" is beneath his spiritual language, for such a hermeneutics of suspicion would cast Shigematsu's practice of indiscriminate hospitality as a manipulative, constructive strategy behind the scenes at Tenth, a practice against which we have argued. ${ }^{6}$ Agreeing with Milbank (2006, p.102) that we must cast a "“meta-suspicion' on the possibility of suspicion itself" in religious studies, I resist the Durkheimian iconoclasm that relegates religious "speculation" to irrelevance because we disagree with Durkheim's central tenet that religion is merely social (DURKHEIM, 1915, p.478). While highlighting Tenth's historic homogeneity as a white affluent congregation, these stories show that Shigematsu's evangelical theology and mystical prayer life have transformed the church into a sociologically heterogeneous space in terms of ethnicity, class, and even religion. We suggest that Tenth's openness to difference is best interpreted through Shigematsu's own understanding that the church is not a place where consensus needs to be constructed, but as a complex space that is divinely gifted to church leaders in which they can demonstrate the indiscriminate hospitality of the Gospel (see MILBANK, 1997; 2006; VOLF, 1996; 2005).

\section{Mysticism, intimidation, and the artistry of God: practicing difference with Ken Shigematsu}

\footnotetext{
${ }^{5}$ Certainly, as Nienkirchen (1992) and Reid (1997) point out, such evangelical mysticism also follows in a Christian and Missionary Alliance socio-theological paradigm as a proto-Pentecostal revivalist movement.

${ }^{6}$ While it may be argued that we have a conflict of interest here to paint Shigematsu in a good light, our paper has emphasized that Shigematsu's pastoral practice is not economically driven but can in fact be seen as a narrative of strategic blunders and offences to a conventional, established church. We also note that every researcher, including ourselves, will have their own positionalities and "conflicts of interest" because of personal and professional affinities. Our approach is not ethnographic but reflective in its analysis of the theological traditions that have been spatialized at Tenth. Further studies that may be more ethnographic in nature may follow a different methodology from ours, but we encourage them to engage this emerging conversation in theology and religious studies that casts a "meta-suspicion" on a suspicion that there is nothing beyond the merely social. We also note that Tse (2010) has also explored congregational settings where strategies of homogeneous congregational construction are really at work in everyday habits and that our claim that Tenth Avenue Alliance Church is an irreducibly Christian space does not mean that we are closed to possibilities that some congregations are in fact internally contentious over their own social constructions, as Tenth once was.
} 
In the mid-1990s, Ken Shigematsu became the unlikely Asian Canadian pastor of Tenth Avenue Alliance Church, a historic Anglo-Saxon church in Vancouver. Familiar with Asian American congregational models, Shigematsu had co-planted a mixed-generation Asian church with Dave Gibbons called Newsong in Orange County, California in the early 1990s (see TRAN, 2010b, p.42). Himself a Canadian, Shigematsu's work visa that permitted him to work in America expired one year after planting the church. To preserve his legal status, he had to return to Canada. He began to live with a childhood friend in White Rock on Marine Drive next to the Canada-US border.

Shigematsu describes a mystical experience he had at this friend's house as launching him into pastoral ministry in a homogeneous, historic Anglo-Saxon congregation. Fasting and praying for five days, he felt the words "Tenth Avenue Alliance" come to mind on the third day, even though he had had no prior connection to the church. By the fifth day, the word "senior pastor" emerged. He wondered at this oddity because he was only 29 years old with no aspirations to become a senior pastor, much less at an Anglo-Saxon church. But obedient to the vision, he visited Tenth and discovered that the church was filled with white Anglo-Saxon senior citizens, completely different from Newsong, where the median age had been 23 and the demographic had been largely second-generation Asian American. Even odder, Tenth had a senior pastor, but over lunch, Shigematsu discovered that this pastor was planning to leave Tenth to find a church more suitable for his children. When Tenth's senior pastor left, Shigematsu applied to be senior pastor without telling the search committee about his mystical experience. Eight months later, he became the senior pastor, despite a controversy over his being young, single, and Japanese Canadian.

Shigematsu soon discovered that the homogeneous, historic church at which he had been hired was shrinking. Tenth had declined from over 1000 attendees in the 1950s to 175 when Shigematsu had arrived; it had also cycled through twenty pastors in the twenty previous years before Shigematsu. His secretary told him: "If the ship sinks now, everyone will blame you because you were the last person at the helm." Shigematsu turned to his mentor Leighton Ford, a brother-in-law of Billy Graham who has had a history of empowering young Christian leaders in Christian ministry all over the world. Shigematsu represents Ford's Canadian protégé (see HAHN; OSTERHAUS, 
2006, p.27-28). When Shigematsu was losing his "inner footing" during his struggles at Tenth, Ford led him on a three-day private retreat to North Carolina where Ford helped him to "hammer out a personal credo and code of ethics" that continues to guide Shigematsu's ministry to the present (HAHN; OSTERHAUS, 2006, p.38). Shigematsu remembers Ford telling him: "First of all, you are young, but don't be timid about using your gifts. You have gifts. Second, remember that God is an artist. He will not lead you to copy anyone else, so seek God for a unique vision for this place." Such a personal vision epitomizes Shigematsu's non-strategy, for instead of pragmatically appropriating church growth strategies that work,Shigematsu learned from Ford to remain in prayer to receive divine gifting and insight for Tenth. As Hahn and Osterhaus (2006, p.28) recall, this advice led Tenth from its situation "in a long decline, unsure of itself and increasingly isolated from its community" to its current state "through time and with much adversity" on Shigematsu's part to "reclaim its roots of evangelistic passion, to reach out beyond its cultural comfort zone, and to embrace the calling of an urban congregation in a complex metropolitan area."

By becoming Tenth's pastor, Shigematsu had already begun to introduce difference into a historic, homogeneous congregation. But true to his Christian sociotheological paradigm, Shigematsu practiced his evangelical theology of difference not as a strategy to construct consensus in his congregation, but out of a series of providential, mystical encounters prior to and during the early years of his pastorate at Tenth. Moreover, such mysticism was coupled by a humility born out of a sense of incapacity. It was out of personal weakness and prayerful poverty, not purposeful leadership and a constructive strategy, that Shigematsu began to envision Tenth a space of evangelical difference.

\section{The Transforming Church: practicing organic difference with a culture of hospitality}

When Tenth became known as a unique heterogeneous congregation, Kevin Ford (2007) featured Tenth as a case study in The Transforming Church. From its history as a white, aging church, it had become a place where people from different backgrounds were congregating. Such diversity included university students, internationals, people of various ethnic backgrounds, international students, artists, professionals, athletes, educators, business leaders, the urban poor, and sex trade 
workers. A story that captures this radical diversity has circulated about how a woman who was walking through Stanley Park one rainy day encountered a pimp that she knew. After fifteen minutes of pouring out her heart to him, the pimp said, "I don't think I can help you, but why don't you try going to Tenth Church?" It was this space that Ford was terming a "transforming church," an ecclesial space where persons of diverse backgrounds were changed to pursue a Christian practice of receiving help from God.

Shigematsu argues that such a space was never consciously constructed but mystically received. Shigematsu had received another revelation in prayer for Tenth to "become a place of inclusion for all people, for people of all different kinds of backgrounds," a place that would not resemble its history as a homogeneous white, aging church. Shigematsu's attempts to strategically plan the church were also supernaturally set-aside: though he had learned in seminary and from church planting to set short-term 100-day goals for the congregation's direction, Shigematsu felt the Holy Spirit saying, "Push aside those goals and just seek me in prayer." Stripped of conscious strategizing in the course of his prayer life, Shigematsu attributes the growth of the church he pastors not to his own efforts but to the dynamism of word of mouth in Vancouver, a network out of his control. This also means that the people who showed up at Tenth were also beyond Shigematsu's manipulation. The difference at Tenth is organic, not manufactured by a constructive strategy.

Indeed, when Kevin Ford attempted to interpret Tenth sociologically through Shigematsu's life story, Shigematsu suggested to him that a better interpretation is that he received a vision to simply create a space of hospitality. Ford and his research assistant told Shigematsu during the interview for The Transforming Church:

Ken, you said that you have never felt truly at home anywhere, that in Vancouver you don't feel completely at home because you are originally from Japan. When you go back to Japan, you don't feel completely at home because you are not Japanese enough by Japanese standards. We have seen in our notes that you have lived in places like Boston, Los Angeles, and now you are back in Vancouver. It seems to us that because you have never felt completely at home anywhere, you are seeking to set a table for people who have not been welcomed in other places. 
To this, Shigematsu replied, "That's probably true, but I believe that this sense of welcome that I believe we are called to offer in our communities is not just a result of my personal sociological history, but the result of the Holy Spirit at work in me and in our community.” Indeed, such hospitality reflects Henri Nouwen's (1986, p.71-72) statement that "hospitality is creating a free space where the stranger can enter and become a friend instead of the enemy...to create emptiness, not a fearful emptiness, but where strangers can enter and discover themselves as created free." As Shigematsu reflects on this, such a space of hospitality is not constructed sociologically but received through prayer as a divine gift. Shigematsu distinctly remembers the Holy Spirit saying to him during prayer, "I will bless this church. This church will survive. It will have a future if you bless those who cannot repay you, if you bless the poor.” For Shigematsu, such a heterogeneous space is created not through strategy but precisely without strategy in defiance of an economic pragmatism that caters to the wealthy and the conventional. Rather, Tenth is received as a gift from God, for it is not constructed by the pastor and his staff but created by the work of the Spirit. Difference in a Christian congregational space cannot be sociologically analyzed; if it is mystically received, it must be interpreted through a socio-theological paradigm where difference is normative, organic, and beyond social construction. To interpret Tenth otherwise is to risk epistemic violence.

\section{The city permit incident: practicing difference with the poor and other religions}

In 2007, Tenth was also embroiled in a conflict with Vancouver City Hall in which Tenth resisted the city's orders to acquire a social services permit for their work with the poor. Tenth had opened a ministry to the homeless called Out of the Cold with their social justice pastor, Don Cowie. In response to this growing work with the poor, the city had begun to see Tenth in a secular light as a social services agency in need of a social services permit. While their application process was under way, the Evangelical Fellowship of Canada contacted Shigematsu to stop the application, for the social services permit might have a domino effect on other churches as well as smaller Jewish, Islamic, and Sikh communities doing work with the poor. Covered by journalist Douglas Todd (2007, p.A1) on the front page of The Vancouver Sun, Tenth's resistance to the permit was also supported by a grassroots coalition called Faith Communities 
Called to Solidarity with the Poor led by Bill Chu (Chinese Christians in Action) and backed by "key Chinese evangelical Christian pastors" and "the leaders of many faiths" (including mainline Protestantism, Islam, Judaism, and Sikhism).

While typical interpretations of the event may focus on religious resistance to the encroachment of the secular, ours highlights the incident as illustrative of Tenth's conviction that it is a hospitable space in the midst of an economically-polarized, multireligious Canadian city. At Tenth, serving the poor is not a publicity strategy; rather, it was again providentially received by Tenth as part of its theological vision through mystical means. Shigematsu had little experience in poverty work, for his previous church plant in Orange County was located in a wealthy, white-collar neighbourhood. His life experience revolved around attending a private American university and then working for SONY. His work with the poor was not a conscious strategy for church prominence but rather provoked by a personal crisis. A homeless young man pseudonymized as Robert had begun to live outside of Tenth under an area where he found cover from the rain and where heat was being naturally expelled from the building. While one of the elders graciously invited him to stay in his furnished carriage house, Robert always inexplicably wandered back to his spot outside of Tenth and eventually froze to death. Shigematsu then asked Don Cowie, an assistant pastor who had a heart for social justice, to visit another socially conscious congregation in Vancouver, Grandview Calvary Baptist Church, to learn how Tenth could get involved in social justice and charity ministry to the poor. The result was Out of the Cold, a service that currently reaches an average of 100-170 people with a hot meal on Monday evenings, 90-110 people for Tuesday noon lunches, and 25 people who stay overnight and receive a hot breakfast the next morning. It was this ministry that the city interpreted as the work of a social service agency, not a church, so Vancouver City Hall required them to acquire a social services permit.

For Shigematsu, the city permit incident is to be interpreted not so much as religious contestation against a secular "policing of the sublime" (MILBANK, 2006, p.106), but rather as a part of Tenth's mission to practice difference both with the poor and with other religions. ${ }^{7}$ Indeed, as Tenth's senior associate pastor Mardi Dolfo-Smith

\footnotetext{
${ }^{7}$ Indeed, here we are following another facet of Milbank's (2006) argument that the city of God is meant to be a space where difference is seen as harmonic, not a provocation to contestation, because the Christian creed emphasizes charity as the result of the forgiveness of sins.
} 
told the press, Tenth understands serving the poor as "something we're commanded to do" and "an article of faith," for such actions foster the church's commitment to being a space of difference (see BELLETT, 2007, p.A6). While Tenth was prepared to acquire a permit for this ministry so as not to make trouble with the city, Shigematsu and his staff ultimately decided against completing the application not because a permit would encroach on Tenth's ability to serve the poor but because this licensing would set an inhospitable precedent to be followed by other religious congregations that may be smaller and less well-endowed than Tenth. Shigematsu wanted to have a positive domino effect to enable other faith communities, including Jewish, Buddhist, Muslim, and Sikh congregations, to start shelter ministries with the homeless as part of their religious practice, not as social service agencies needing permits. Indeed, the activism against the permit served other (even non-Christian) religious groups, not Tenth, for permits would cost other congregations fees that would be taken out of small operating budgets. The permit controversy was not about asserting Tenth's religious rights in opposition to the city. It was about caring for Tenth's multi-religious neighbours as all religious congregations cared for the poor as an integral part of their sociotheological paradigms. Indeed, Shigematsu's evangelical theology of difference is wide enough to include not only socioeconomic but religious heterogeneity in urban space, for the vision he received mystically was to bless the poor, to welcome all, and to be a blessing to those who could not repay Tenth, including small congregations from religions different from evangelical Protestantism. The activism against the permit was read by Shigematsu not as a form of political contestation against the city but as a hospitable act toward Vancouver, its multiple religious groups, and the economically disadvantaged groups that they all served together.

Faithfulness to the Gospel: practicing difference with attendees who do not profess Christian faith

This openness to serving other religions is not a compromise of Tenth's evangelicalism, for Shigematsu's emphasis at Tenth is on the preaching of Jesus Christ as the fulcrum of Christian faith and unity. Indeed, Shigematsu reports that his preaching is at times criticized for over-emphasizing Christ at the expense of other religious leaders. His typical response is: "Once you get to know Jesus Christ you will 
come to understand how amazing he is, and I think you will appreciate more why we at Tenth emphasize Christ so much.” By emphasizing Jesus Christ, Shigematsu suggests that he is making space for difference, not univocally closing off religious options. In so doing, Tenth is not even a space of religious homogeneity, although it is a selfidentifying evangelical Christian congregation that believes in the definitiveness of Jesus as the way to life.

Rather than a place where theological consensus is constructed, Tenth is better interpreted as a space where the message of Jesus Christ is openly preached to a religiously heterogeneous congregation. Shigematsu received this vision through yet another providential encounter, this one with Tim Keller, the senior pastor for Redeemer Presbyterian Church in Manhattan. At a retreat in North Carolina where they met, Keller told Shigematsu, "If you preach like non-Christians are present, if you are mindful of them, then non-Christians will start coming" (see STETZER; BIRD 2010, p.69; see also KELLER, 2008). Preaching Christ with this paradigm presupposes the presence of theological and religious difference in a congregation so that Christ is not presented as an agent who imposes homogeneous construction but who facilitates continued heterogeneous mixing. A non-Christian friend of Shigematsu's recently told him, "I feel really comfortable inviting my friends who are not Christians to Tenthartists, writers, intellectuals - because I know they are going to hear a message that they

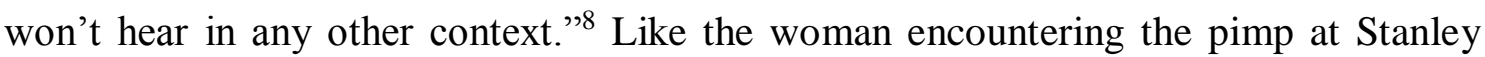
Park, this friend's relational invitations epitomize word-of-mouth growth even among persons who do not profess evangelical Protestant Christian faith. With no advertising strategy, such organic growth has led to a congregation that averages 1600 attendees on regular Sundays and 3000 to 4000 who show up at Christmas; these numbers do not differentiate professing Christians from those who are not. Moreover, guests are often brought into church activities such as Alpha where the Christian faith is introduced to them over meals and discussions. Because they are part of multiple individual networks, the guests who come to Tenth are necessarily diverse, even in a religious sense, for the friends who are doing the inviting may not even be professing Christians themselves and may come from a variety of political, economic, social, ethnic, and even religious

\footnotetext{
${ }^{8}$ Shigematsu is quick to point out that this is his friend speaking, not himself. Far from seeing Tenth as the only church to preach Jesus like this, he acknowledges that many evangelical congregations in Vancouver also preach a very similar evangelical message.
} 
backgrounds. They come to a space where Jesus Christ is preached, but that space is filled with people with multiple socio-economic and religious intersections to whom Jesus may speak differently.

Such a sociotheological paradigm that embraces religious difference within the congregation is an evangelical Christian one at heart. For Shigematsu, practicing difference is the epitome of faithfulness to the Christian Gospel. As he was cleaning out old files in his office with his assistant, Ken Nixon, he discovered an old prayer letter where he had written:

I am now pastoring in Vancouver at Tenth Church. I don't think that God has called us necessarily to be a big church or a famous church. I believe that God is simply calling us to be faithful, faithful to the Gospel, faithful where we receive all the people that God is calling to Tenth, faithful to proclaim Christ... his holiness, his beauty, his love.

Shigematsu's evangelicalism is based on an inclusive love stemming from an ethic of hospitality that embraces "all the people God is calling to Tenth," not a homogeneous group that Shigematsu is trying to attract. The active agent in Tenth's unintended church growth is God, not Shigematsu. This interpretation thus breaks out of what Charles Taylor (2007) has called an "immanent frame" and "closed-world structures" that "buffer" modern "conditions of belief" against the possibility of divine action in the world. The preaching of Jesus Christ is not a homogenizing act of constructing theological consensus. Rather, it is an act of welcome to believers and nonbelievers alike into a heterogeneous space, just as the resistance to the social services permit was an act of service to both Christians and groups of different religious persuasions. To practice exclusion at Tenth would be an unfaithful compromise of the Gospel, a betrayal of Shigematsu's evangelical theological convictions exegetically derived from the New Testament, mystically received in prayer, and providentially advised by older evangelical pastors. Shigematsu does not construct his congregation; he prays over it as God's gift to him and his fellow leaders as a space where all are welcome to hear the message of Jesus Christ. 


\section{Conclusion: Tenth Avenue Alliance Church and the Interruptions of Asian Canadian Christian Studies}

I have argued in this article that the heterogeneity within the congregation at Tenth Avenue Alliance Church in Vancouver, BC is best interpreted through the evangelical sociotheological paradigm of its senior pastor, Ken Shigematsu. This study provides a theological framework from the perspective of Tenth's senior pastor for potential ethnographies of similar Christian congregations to avoid the imposition of conventional economistic categories on congregations that aim to be unconventional in their expression of the Christian Gospel in space. Indeed, further research may illumine the multiplicity of ethnic, socio-economic, and religious networks that intersect with Tenth that are outside of the control of Shigematsu and his staff. Although Tenth is indeed a large church, it cannot be interpreted through sociological paradigms that emphasize the construction of homogeneity as a strategy for church growth, for its size is unintentional and its demographic is radically diverse. Instead, I have examined the sociotheological paradigm of Ken Shigematsu's pastoral tenure at Tenth since the 1990s through his New Testament exegetical framework, his Christian and Missionary Alliance denominational affiliation, and his mystical encounters with the divine in prayer and connections to ancient Christian practices. I have demonstrated that Tenth is an organic evangelical Christian congregation that continually makes space for difference while it remains faithful to Jesus Christ and the Christian Gospel by conceiving of the church as God's gift to them as a place from which to show hospitality.

This study of Tenth Church implies that the future of Asian Canadian Christian congregations cannot lie in the construction of homogeneous ethnic religious spaces. This resistance to pan-Asian homogeneity falls under the rubric of what Rudy Busto (2003) has called the need to "disOrient" orientalist assumptions about Asian North American religions, including the stereotype that Asians form Asian-only congregations. As Chris Lee (2008) suggests, Asian Canadian studies are better articulated as strategic resistances to the Canadian legacy of anti-Asian sentiment, not apolitical representations of Asian cultural characteristics in multicultural Canada. Shigematsu's younger brother Tetsuro illustrates Lee's point in his YouTube channel, 
ShiggyTV. ${ }^{9}$ A notable video that interviews mixed-ethnic fraternities at the University of British Columbia at Vancouver refutes Stephanie Findlay and Nicholas Köhler's (2010) article in MacLean' $s{ }^{10}$ that has called several major Canadian universities "too Asian" because their Asian students supposedly do not mix with non-Asians (SHIGGYTV, 2010). But through Ken Shigematsu, I have argued that Asian Canadian Christian studies transcend such strategic contestations against the ongoing legacy of anti-Asian racism. Rather, the Christian element emphasizes Asian bodies as part of the Triune God's gift of difference to confound the conservatism of homogeneous religious establishments. In this sense, the God of the Christian Scriptures is the actor who used Ken Shigematsu's body, prayer life, and pastoral leadership to re-direct the false purity of Tenth Avenue Alliance Church into a space of radical hospitality.

Such Asian Canadian Christian reflections on heterogeneity mirror Jonathan Tran's (2010a; 2010b) paradox of there simultaneously being no future for Asian American Christianity and a definitive future for Christianity as Asian American. For Tran, Asian North American homogeneity is a congregational dead-end leading to contestations over false purity (see Tse 2010) whereas the assertion of Asian North American identities de-whitens the face of North American Christianity. Tran (2010b) has called this process the "yellowing" of Christianity, interrupting American evangelicalism's false purity of whiteness. ${ }^{11}$ In Tran's words, Shigematsu has "yellowed" his own congregation as an Asian Canadian Christian, yet this "yellowing" came about not through his own constructive actions but through his mystical reception of Tenth as a hospitable, heterogeneous complex space (TRAN, 2010b, p.55-56; see MILBANK, 1997; 2006). Following Tran's theological insight in a Canadian context

\footnotetext{
9 Tetsuro Shigematsu is an established television and radio personality in Canada. He was Bill Richardson's replacement from 2004-2005 for CBC Radio One's afternoon show, The Round-up, as the first visible minority to host a radio show in Canada. He was also a writer for the CBC's television comedy show This Hour Has 22 Minutes in the 1990s. From 1993-1996, he performed a one-man show titled Rising Son in international settings. More recently, he directed an independent film, Yellow Fellas (2007), and was featured on the cover of the Spring 2005 issue of Ricepaper Magazine as a "sexy Asian man" to refute the stereotype of the asexual Asian male.

${ }^{10}$ MacLean's is a weekly national news magazine that is subsidized by the Canadian federal government.

${ }^{11}$ Tran $(2010$ b, p. 37, n.1) admits that "dubbing Asian Americans 'Yellow' is hardly inclusive" because it fails to include the diversity of all Asian Americans, including "South Asians, Pacific Islanders, underrepresented Asian minorities such as the Hmong, etc." However, he uses "yellow" in a "purposefully limited way" as a "rhetorical device" to narrate the experiences of Asian Americans who feel caught between the dichotomy of black and white. To "yellow" Christianity is to infuse a theological tradition that has been overly represented as white with the gift of an Asian American Christianity. We have shown that this divine gift has been given to Tenth in the person of Ken Shigematsu as an Asian Canadian Christian.
} 
(see also LEE, $2007^{12}$ ), we have argued that Tenth challenges the simple conventional wisdom of congregational homogeneity in church growth and the sociology of religion and that the task of Tenth where some Asian Canadians congregate is to show off the Christian faith as constantly welcoming the stranger into fellowship with Jesus (see LEY; TSE, 2011). Indeed, there are some congregations that do attempt to manufacture consensus through economic logics as a resistance to secularism and cultural change. This paper has simply suggested that Tenth Avenue Alliance Church is no longer one of them.

\section{Acknowledgements}

I am grateful to the editorial work of Joyce C.Y. Chan at Carey Theological College for this idea. I also thank Ken Shigematsu and Ken Nixon for their insight and help while editing this paper.

\section{REFERENCES}

ASAD, T. Genealogies of Religion: Discipline and Reasons of Power in Christianity and Islam. Baltimore: The Johns Hopkins University Press, 1993.

ASAD, T. Formations of the secular: Christianity, Islam, modernity. Stanford, CA: Stanford University Press, 2003.

BEATTIE, L.; LEY, D. The German immigrant church in Vancouver: service provision and identity formation. Die Erde, Vol.134, 2003, p.3-22.

BEBBINGTON, D.W. Evangelicalism in Modern Britain: A History from the 1730s to the 1980s. London: Unwin Hyman, 1989.

BELLETT, G. City to re-examine decision to require permit for helping poor; the development board sparked a conflict between city hall and a wide spectrum of religious organizations that offer the needy food, clothing and shelter. The Vancouver Sun, A6, 25 August, 2007.

\footnotetext{
${ }^{12}$ Chris Lee (2007) demonstrates that the boundaries of Asian American and Asian Canadian studies are porous, especially after the transnational turn in Asian American studies. As the co-planter of the Asian American church Newsong in Orange County and as an Asian Canadian senior pastor of Tenth Avenue Alliance Church, Ken Shigematsu epitomizes Lee's point, albeit not purposefully and strategically.
} 
BETZ, H. D. Galatians: A Commentary on Paul's Letter to the Churches in Galatia. Philadelphia: Fortress, 1979.

BONHOEFFER, D. The Cost of Discipleship. 1937/1948. London: SCM Press, 2001.

BUSTO, R. V. DisOrienting subjects: reclaiming Pacific Islander/Asian American religious traditions. In: IWAMURA, J.; SPICKARD, P. (eds.). Revealing the Sacred in Asian America. New York and London: Routledge, 2003.

CHAI, K. Competing for the second generation: English-language ministry at a Korean Protestant church. In: WARNER, R. S.; WITTNER, J. G. Gatherings in Diaspora: Religious Communities and the New Immigration. Philadelphia: Temple University Press, 1998.

CHAO, A.; YU, S. Serving God with Heart and Soul: The Life of Pastor Augustus Chao. Vancouver: Canadians for Historical Justice and Racial Reconciliation, 2002.

DAGGERS, J. Thinking "religion": the Christian past and interreligious future of religious studies and theology. Journal of the American Academy of Religion, Vol.78, No.4, 2010, p.961-990.

DITTMER, J.; STURM, T. (eds.). Mapping the End Times: American Evangelical Geopolitics and Apocalyptic Visions. Aldershot: Ashgate Publishing, 2010.

DUNN, J. D. G. Jesus, Paul, and the Law. Louisville: Westminster John Knox, 1990.

DURKHEIM, E. The Elementary Forms of Religious Life. New York and London: The Free Press and Collier, 1915.

DWYER, C. Contradictions of community: questions of identity for young British Muslim women. Environment and Planning A, Vol.31, No.1, 1999a, p.53-68.

Veiled meanings: young British Muslim women and the negotiation of differences. Gender, Place, and Culture, Vol.6, 1999b, p.5-26.

FALAH, G.; NAGEL, C. (eds.). Geographies of Muslim Women: Gender, Religion, and Space. New York: Guildford Press, 2005.

FINDLAY, S.; KÖHLER, N. The enrollment controversy: worries that efforts in the U.S. to limit enrollment of Asian students in top universities may migrate to Canada. [Formerly titled: Too Asian?] MacLean's, 10 November, 2010. Disponível em: <http://www2.macleans.ca/2010/11/10/too-asian/> Acesso: 27/05/2011.

FORD, K. G. Transforming Church: Bringing Out the Good to Get to Great. Colorado Springs: David C. Cook, 2007.

GOKARIKSEL, B. Beyond the officially sacred: Religion, secularism, and the body in the production of subjectivity. Social and Cultural Geography, Vol.10, No.6, 2009, p.657-674. 
GEORGE, C. F. Prepare Your Church for the Future: Introducing the Meta-Church: Large Enough to Celebrate: Small Enough to Care. Grand Rapids: Revell, 1991.

GEORGE, C. F.; BIRD, W. How to Break Growth Barriers: Capturing Overlooked Opportunities for Church Growth. Grand Rapids: Baker, 1993.

HAHN, T.; OSTERHAUS, J. The Mentoring Tree: A Leadership Legacy of Leighton Ford. Charlotte: Leighton Ford Ministries, 2006.

HARTZFELD, D. F.; NINEKIRCHEN, C. The Birth of a Vision: Essays on the Ministry and Thought of Albert B. Simpson. Beaverlodge, AB: Buena Book Services, 1986.

JEREMIAS, J. New Testament Theology, vol. 1: The Proclamation of Jesus. London: SCM, 1971.

JEWETT, R. The agitators and the Galatian congregation. New Testament Studies, Vol.30, 1984, p.198-211.

Juergensmeyer, M. 2009 Presidential Address: Beyond words and war: the global future of religion. Journal of the American Academy of Religion, Vol.78, No.4, 2010, p.882-895.

KELLER, T. The Reason for God: Belief in an Age of Skepticism. New York: Penguin, 2008.

KOELlER, D.W. Julian the Apostate - Letter to Arsacius. Then Again. 2005. Disponível em: <http://www.thenagain.info/Classes/Sources/Julian.html> Acesso: 19/05/2011.

KONG, L. Mapping 'new' geographies of religion: politics and poetics in modernity. Progress in Human Geography, Vol.25, No.2, 2001, p.211-233.

Global shifts, theoretical shifts: changing geographies of religion. Progress in Human Geography, 2010, p.1-22.

LEE, C. M. The lateness of Asian Canadian studies. Amerasia, Vol.33, No.2, 2007, p.1-18.

Enacting the Asian Canadian. Canadian Literature 199, 2007, p.28-44.

LEY, D. Between Europe and Asia: The case of the missing sequoias. Ecumene, Vol.2, 1995, p.187-212.

Seeking homo economicus: The Canadian state and the strange story of the Business Immigration Program. Annals of the Association of American Geographers, Vol.93, No.2, 2003, p.426-441. p.2057-2074.

The immigrant church as ethnic service hub. Urban Studies, Vol.45, 2008, 
Blackwell, 2010.

LEY, D.; KOBAYASHI, A. Back to Hong Kong: return migration or transnational sojourn? Global Networks, Vol.5, 2005, p.111-128.

LEY, D.; TSE, J. K. H. Homo religiosus? Religion and immigrant subjectivities. In: KONG, L.; OLSON, E.; HOPKINS, P. Religion and Place: Identity, Community, and Territory. New York: Springer, 2011.

LI, P. The rise and fall of Chinese immigration to Canada: newcomers from Hong Kong Special Administrative Region of China and Mainland China, 1980-2000. International Migration, Vol.43, No.3, 2005, p.9-34.

LOGAN, R. E.; GEORGE, C. F. Leading and Managing Your Church. Grand Rapids: Baker, 1996.

MACDONALD JR, P. A. Studying Christian theology in the secular university. Journal of the American Academy of Religion, Vol.78, No.4, 2010, p.991-1024.

MCGAVRAN, D. A. Bridges of God: A Study in the Strategy of Missions. 1954. Eugene, OR: Wipf and Stock Publishers, 2005.

MILBANK, J. The Word Made Strange: Theology, Language, Culture. Oxford and Malden, MA: Blackwell, 1997.

MILBANK, J. Theology and Social Theory: Beyond Secular Reason, $2^{\text {nd }}$ ed. Oxford and Malden, MA: Blackwell, 2006.

MITCHELL, K. Crossing the Neoliberal Line: Pacific Rim Migration and the Metropolis. Philadelphia: Temple University Press, 2004.

MITCHELL, K.; OLDS, K. Business networks and the globalization of property markets inthe Pacific Rim. In: OLDS, K.; YEUNG, H. (eds.). The Globalization of Chinese Business Firms. Oxford: Oxford University Press, 2000.

NIENKIRCHEN, C. W. A. B. Simpson and the Pentecostal Movement: A Study in Continuity, Crisis, and Change. Peabody, MA: Hendrickson, 1992.

NOUWEN, H. Reaching Out: The Three Movements of the Spiritual Life. New York: Image Books, 1986.

ORSI, R. A. (ed.). Gods of the City: Religion and American Urban Landscape. Bloomington: University of Indiana Press, 1999.

Snakes alive: Resituating the moral in the study of religion. In: CASTELLI, Elizabeth; RODMAN, Rosamond C. (eds.). Women, Gender, Religion: A Reader. New York: Palgrave, 2001. 
PRIMIANO, L. N. Intrinsically Catholic: Vernacular Religion and Philadelphia's "Dignity." Unpublished PhD dissertation, University of Pennsylvania, Department of Religious Studies, 1993.

REID, D. R. Towards a Fourfold Gospel: A.B. Simpson, John Salmon, and the Christian and Missionary Alliance in Canada. In: RAWLYK, G.A. (ed.). Aspects of the Canadian Evangelical Experience. Montreal, Kingston, London, and Buffalo: McGill Queen's University Press, 1997.

REITZ, G. W. A. B. Simpson: urban evangelist. Urban Mission, Vol.8, No.3, 1991, p.19-26.

REYNOLDS, L. Footprints: The Beginnings of the Christian and Missionary Alliance in Canada. Beaverlodge, AB: Buena Book Services, 1982.

Rebirth: The Redevelopment of the Christian and Missionary Alliance in Canada. Beaverlodge, AB: Evangelistic Enterprises, 1992.

SANDERS, E. P. Paul and Palestinian Judaism. London: SCM, 1977.

Paul, the Law, and the Jewish People. Minneapolis: Fortress, 1983.

SHIGEMATSU, K. Ethnic must become multiethnic. Christian Info News, Vol.16, No.4, 1996, p.7.

Living for Christ when dying is gain. Loving God by Following the Way of Jesus. Sermon at Tenth Avenue Alliance Church. 13 March, 2011a.

Is there a future for Asian Canadian churches? Asian Mission in Canada: Inaugural Conference, Regent College, Vancouver, BC, 21-22 March, 2011 b.

SHIGGYTV. MacLean's “Too Asian.” 27 November, 2010. Disponível em: <http://youtu.be/CDMUNypqnSY> Acesso: 19/05/2011.

SKELDON, R. (ed.). Reluctant Exiles? Migration from Hong Kong and the new overseas Chinese. Armonk NY: M. E. Sharpe, 1994.

STARK, R.; FINKE, R. Acts of Faith: Explaining the Human Side of Religion. Berkeley, Los Angeles, and London: University of California Press, 2000.

STETZER, E.; BIRD, W. Viral Churches: Helping Church Planters Become Movement Makers. San Francisco: Jossey-Bass, 2010.

STUMP, R. W. The Geography of Religion: Faith, Place, and Space. Lanham, MD: Rowman and Littlefield, 2008.

TAYLOR, C. A Secular Age. Cambridge, MA and London: Harvard University Press, 2007. 
THOMPSON, A. E. The Life of A. B. Simpson. Whitefish, MT: Kessinger, [1920] 2008.

TODD, D. Religious leaders take on city hall; permit policy would limit services to poor and homeless. The Vancouver Sun, 18 August, 2007, p.A1.

TOZER, A. W. Wingspread: A. B. Simpson, a Study in Spiritual Altitude. Harrisburg, PA: Christian Publications, 1943.

TRAN, J. First Keynote Presentation: why Asian American Christianity has no future: the over against, leaving behind, and separated from of Asian American Christian identity. Society of Asian North American Christian Studies, Vol.2, 2010a, p.13-36.

Second Keynote Presentation: why Asian American Christianity is the future: holding it together in yellow Christianity. Society of Asian North American Christian Studies, Vol.2, 2010b, p.37-56.

TSE, J. K. H. Making a Cantonese-Christian family: quotidian habits of language and background in a transnational Hongkonger church. Population, Space, Place: A Journal of Population Geography. Special Issue: Migration and Everyday Matters: Materiality and Sociality. Vol.17, No.6, 2010, p.640-652.

TSENG, T. Second-generation Chinese evangelical use of the Bible in identity discourse in North America. Semeia, Vol.90/91, 2002, p.251-267.

VOLF, M. Exclusion and Embrace: A Theological Exploration of Identity, Otherness, and Reconciliation. Nashville: Abingdon, 1996.

Free of Charge: Giving and Forgiving in a Culture Stripped of Grace. Grand Rapids: Zondervan, 2005.

WANG, J. "His Dominion" and the "Yellow Peril": Protestant Missions to Chinese Immigrants in Canada, 1859-1967. Waterloo, ON: Wilfrid Laurier Press, 2006.

WARREN, R. The Purpose Driven Church: Growth Without Compromising Your Message and Mission. Grand Rapids: Zondervan, 1995.

WARNER, R. S. Introduction: immigration and religious communities in the United States. In: WARNER, R. S.; WITTNER, J. G. (eds.). Gatherings in Diaspora: Religious Communities and the New Immigration. Philadelphia: Temple University Press, 1998.

A Church of Our Own: Disestablishment and Diversity in American Religion. Piscataway: Rutgers University Press, 2005.

WARNER, R. S.; WITTNER, J. G. (eds.). Gatherings in Diaspora: Religious Communities and the New Immigration. Philadelphia: Temple University Press, 1998.

WATERS, J. Flexible families? 'Astronaut' households and the experiences of lone mothers in Vancouver, British Columbia. Social and Cultural Geography, Vol.3, 
No.2, 2002, p.117-134.

Flexible citizens? Transnationalism and citizenship amongst economic immigrants in Vancouver. Canadian Geographer, Vol.3, 2003, p.219-234.

Geographies of cultural capital: education, international migration and family strategies between Hong Kong and Canada. Transactions of the Institute of British Geographers, Vol.31, 2006, p.171-192.

WILFORD, J. Sacred archipelagos: geographies of secularism. Progress in Human Geography, Vol.34, No.3, 2010, p.328-348.

WRIGHT, N. T. The New Testament and the People of God. Minneapolis: Fortress, 1992.

YANG, F. Tenuous unity in a contentious community: cultural and religious dynamics in a Chinese Christian church. In: WARNER, R. S.; WITTNER, J. G. (eds.). Gatherings in Diaspora: Religious Communities and the New Immigration. Philadelphia: Temple University Press, 1998.

YU, H. Introduction: Refracting Pacific Canada: seeing our uncommon past. BC Studies, Vol.156/157, 2008, p.5-10.

Recebido: $14 / 05 / 2014$

Received: 05/14/2014

Aprovado: 19/08/2014

Approved: 08/19/2014 